WSRC-TR-2002-00431

\title{
ESTIMATE OF LEGACY TRITIUM IN BUILDING 232-H TRITIUM FACILITY, SAVANNAH RIVER SITE
}

Elliot A. Clark

30 September 2002

Westinghouse Savannah River Company Aiken, SC 29808

Prepared for the U.S. Department of Energy under Contract DE-AC09-96SR18500 
This document was prepared in conjunction with work accomplished under Contract No. DE-AC09-96SR18500 with the U. S. Department of Energy.

\section{DISCLAIMER}

This report was prepared as an account of work sponsored by an agency of the United States Government. Neither the United States Government nor any agency thereof, nor any of their employees, makes any warranty, express or implied, or assumes any legal liability or responsibility for the accuracy, completeness, or usefulness of any information, apparatus, product or process disclosed, or represents that its use would not infringe privately owned rights. Reference herein to any specific commercial product, process or service by trade name, trademark, manufacturer, or otherwise does not necessarily constitute or imply its endorsement, recommendation, or favoring by the United States Government or any agency thereof. The views and opinions of authors expressed herein do not necessarily state or reflect those of the United States Government or any agency thereof.

This report has been reproduced directly from the best available copy.

Available for sale to the public, in paper, from: U.S. Department of Commerce, National Technical Information Service, 5285 Port Royal Road, Springfield, VA 22161, phone: (800) 553-6847, fax: (703) 605-6900

email: orders@ntis.fedworld.gov

online ordering: http://www.ntis.gov/help/index.asp

Available electronically at http://www.osti.gov/bridge

Available for a processing fee to U.S. Department of Energy and its contractors, in paper, from: U.S. Department of Energy, Office of Scientific and Technical Information, P.O. Box 62, Oak Ridge, TN 37831-0062,

phone: (865)576-8401,

fax: (865)576-5728

email: $\underline{\text { reports@ adonis.osti.gov }}$ 


\title{
SMTD
}

STRATEGIC MATERIALS TECHNOLOGY DEPARTMENT
Keywords: Deactivation
Tritium Facility
Radiological Characterization
232-H

Retention: Permanent

\section{ESTIMATE OF LEGACY TRITIUM IN BUILDING 232-H TRITIUM FACILITY, SAVANNAH RIVER SITE}

\author{
Elliot A. Clark \\ Materials Compatibility and Joining Technology Group \\ Materials Technology Section
}

ISSUED: $\quad 30$ September 2002

Unclassified

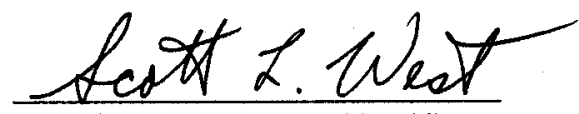

Authorized Derivative Classifier

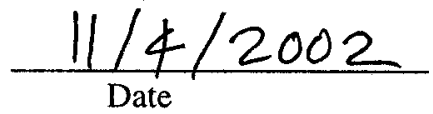


SRTC

SAVANNAH RIVER TECHNOLOGY CENTER, AIKEN, SC 29808

Westinghouse Savannah River Company.

Prepared for the U.S. Department of Energy under Contract DE-AC09-96SR18500

Document: WSRC-TR-2002-00431

Title: $\quad$ Estimate of Legacy Tritium in Building 232-H Tritium Facility, Savannah River Site

APPROVALS

Elgar a lad

DATE: 4 November 2002

E.A. Clark, Author

MATERIALS COMPATIBILITY AND JOINING TECHNOLOGY GROUP MATERIALS TECHNOLOGY SECTION

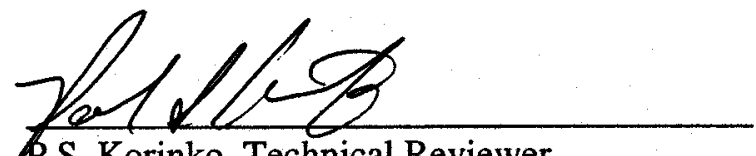

DATE: $11 / 4 / 02$

MATERIALS COMPATIBILITY AND JOINING TECHNOLOGY GROUP MATERIALS TECHNOLOGY SECTION
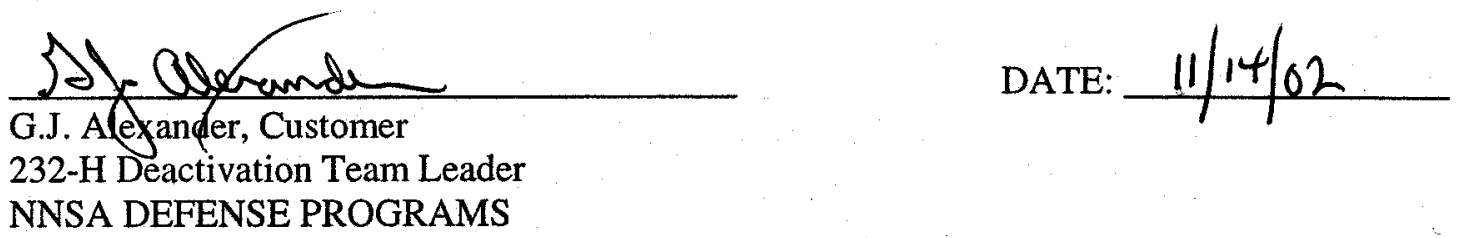

Scott L. We at

DATE: $11 / 4 / 2002$

S. L. West, Manager,

MATERIALS COMPATIBILITY AND JOINING TECHNOLOGY GROUP

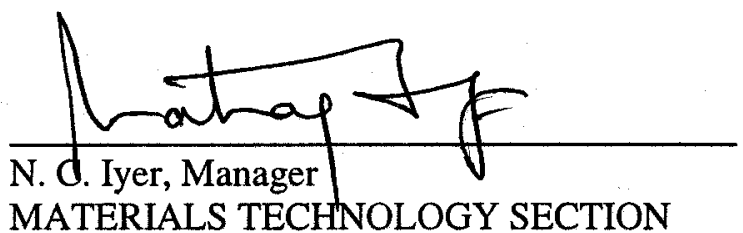

DATE: $11 \mid 06 / 02$

ii 
WSRC-TR-2002-00431

\section{ESTIMATE OF LEGACY TRITIUM IN BUILDING 232-H TRITIUM FACILITY, SAVANNAH RIVER SITE}

\section{CONTENTS}

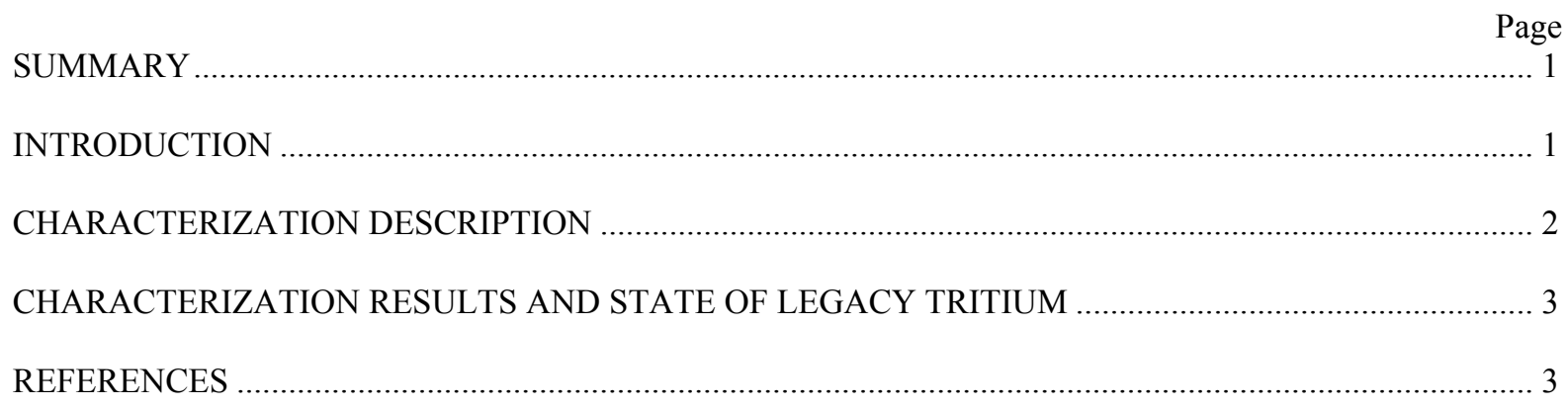

\section{TABLES}

I. Listing of Components and Tritium Characterization for Building 232-H .................................4

II. LP-50 tritium data, MTF, FTF, and Total Line I and Line II 232-H Internal Surface Area and

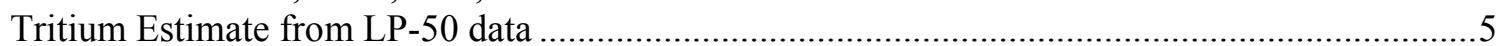

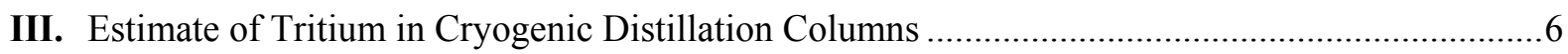

VI. Estimate of Tritium in one Thermal Diffusion Column............................................................6 
This page intentionlly blank. 


\title{
ESTIMATE OF LEGACY TRITIUM IN BUILDING 232-H TRITIUM FACILITY, SAVANNAH RIVER SITE
}

\author{
Elliot A. Clark
}

\section{SUMMARY}

The amount of legacy tritium existing in the tritium processing system in Building 232-H at the Savannah River Site after this building is deactivated is estimated to be on the order of 37 grams of $\mathrm{T}_{2}$, or about 350,000 curies. This estimate was calculated by creating an inventory of components (including equipment, pipe, tanks, and other facilities) that will remain in 232-H after it is deactivated. Estimates of tritium in many components were taken from existing estimates used for waste disposal. For pipe and tanks, the tritium content was calculated using the results of previous measurements of tritium in samples removed from a used container were scaled to the surface area exposed to the process gas. It is shown that over $80 \%$ of the legacy tritium will reside in polymers, used for gaskets and in valves. It is believed that the tritium in polymers will be released if exposed to excessive heating or a fire.

\section{INTRODUCTION}

Building 232-H at the Savannah River Site has processed tritium since 1958. Major operations in this building include tritium extraction from irradiated targets, gas purification, isotope separation, water vapor processing, and loading and unloading shipping containers. The Materials Test Facility (MTF) is located in 232-H, where reservoir life storage and other tritium-related research and surveillance programs occur. Other facilities located in 232-H include a Function Test Facility (FTF) and portions of Reservoir Surveillance Operations (RSO).

Current plans are to deactivate Building 232-H by 2006. (The Tritium Facility Modernization and Consolidation project is reproducing those process functions currently conducted in $232-\mathrm{H}$ in other facilities. The CLWR-Tritium Extraction Facility project will enable tritium extraction from the new Commercial Light Water Reactor targets.) The deactivated building will have no power or utilities, and can be described as being "cold, dark, and dry". All connections with ongoing buildings will be separated and capped. The processing system will be flushed with argon and remain closed. Many process beds (zeolite, and uranium beds, for example) will be removed and the connections capped. An externally controlled exhaust fan will maintain a minimal vacuum, and airflow will be maintained in the process hoods. Tritium emissions from the stack will continue to be monitored. Most combustible materials will be removed, including furniture and carpets since no fire detection or suppression systems will be maintained.

It is well known that tritium gas permeates into all components it contacts to some degree. Tritium molecules dissociate on metal surfaces, such as stainless steel, and diffuse as single atoms into the near surface region. Tritium molecules dissolve in polymers, and diffuse throughout the polymer. Tritium can isotopically exchange with hydrogen atoms that are a major constituent of most polymers, and become part of the molecular structure of the polymer. Because of this permeation, components in tritium processing systems that are wetted by tritium will take up significant amounts of it. The amount of tritium permeating into a given component depends significantly on the material, temperature, tritium partial pressure, and the condition of the surface of the material. For example, metal oxides can absorb tritium as can any organic or oil film on surfaces.

This report describes an estimate of how much tritium will be held up in those parts of the 232-H process that will remain in the building after deactivation. The anticipated state of this tritium is also discussed. This information will be used to assess the radiological status of the deactivated facility. 


\section{CHARACTERIZATION DESCRIPTION}

This characterization consists of inventorying the components and systems that will remain in the deactivated 232-H, and compiling estimates for the tritium content of each (Table I below). Tritium characterizations have already been determined for many components such as pumps, valves, gaskets, and so on. These characterizations are used for waste disposal, and are assembled in a database maintained by Defense Programs, the "Curie Content" database in the Tritium Technical Files area of the Tritium Databases server.

An important source of tritium not determined by waste characterization data is the amount of tritium residing on and near the interior surfaces of process pipes and tanks. Several years ago, samples cut from an LP-50 product container (used to transport tritium gas) were removed so the total residual tritium existing in the stainless steel wall could be measured (to enable retired containers to be returned to SRS) [1]. The conditions of exposure to the walls of the LP-50 are very similar to that in the fixed processing system in Building 232-H. Specifically, the temperature (ambient), tritium partial pressure (vacuum up to 2 atmosphere), time (39 years) and material (Type 304L stainless steel) are virtually identical. Because of the similarity of exposure conditions, results from the LP-50 study can be used for a tritium characterization of the 232-H process pipes and tanks. The LP-50 study provides an estimate of the residual tritium concentration per unit area. The amount of tritium able to be exchanged with humidity in air was estimated by monitoring tritium offgassing (using an ion chamber) and performing aqueous leaching experiments. The amount of tritium dissolved in the bulk was estimated by dissolving the stainless steel in a nitric $\mathrm{acid} /$ hydrochloric acid mixture. The tritium that leached into water and that which dissolved in aqua regia was measured using multiple dilutions and liquid scintillation counting.

The other factor in estimating the tritium burden in pipes and tanks in this way requires estimating the size of the system as measured by the total internal surface area of the pipes and tanks exposed to the process gas. Standard practice in tritium systems is to measure the process volume of each and every section of the process (for example, the volume of pipe between all valves and other components). The total surface area (internal) of the exposed pipe and tanks can be estimated using the measured volumes of each section of pipe and each tank, along with typical pipe diameter and tank dimensions [2] (Table II below). The final characterization of residual tritium in pipes and tanks consists of multiplying the specific residual tritium concentration by the estimated internal surface area.

Two cryogenic stills ("cryostills") separated hydrogen isotopes in 232-H. These consisted of a long tube filled with a type of stainless steel packing, coiled into small spring-like pieces. A "re-boiler" was at the bottom of the pack region, and a condenser was at the top. These stills operated at nearly liquid helium temperature. To conservatively estimate the residual tritium in each still, the same residual tritium per unit surface area used for tanks and pipes was employed. The surface area of the packing accounts for most of the surface area in these stills. The geometry of the packing was inferred from a photograph of the packing and measurements at a web site (http://www.lab-glass.com/html/nf/DSTA-LG-6730.html). An engineering drawing of one of the cryostills indicates that about 15 pounds of packing were used. The total surface area was calculated using the density of stainless steel and the geometry of the packing (Table III.). The estimated residual tritium on the packing was much larger than that estimated for the interior of each still, since the surface area of the packing is much greater than the interior surface of the still container. (The packing is employed specifically to increase surface area in distillation columns.)

In addition to the cryogenic stills, four thermal diffusion columns were used to separate hydrogen isotopes. They consisted of a long tube with a platinum wire in the middle. The wire was heated by Ohmic heating (passing an electric current). Since different isotopes have slightly different thermal diffusivities, there is a gradual separation from top to bottom. The main tube of the column that was exposed to tritium was cooled on the outside by water, so the temperature of the exposed surface was approximately ambient temperature. Thus, the legacy tritium is estimated to be the same amount per unit area as in the LP-50 case, and the total tritium is the internal wall surface area times the LP-50 (Table IV below). 


\section{CHARACTERIZATION RESULTS AND STATE OF LEGACY TRITIUM}

Table I contains all of the contributions and totals the estimated quantity of tritium. The sum is about $350,000 \mathrm{Ci}$, or about 37 grams of $\mathrm{T}_{2}$. Also indicated in Table $\mathrm{I}$ is the relative amount of this that resides in polymers, $82 \%$. The vast majority of tritium resides in Type E flange gaskets, made of Buna- $\mathrm{N}$, and in automatic and manual valves. These type of valves are considered to be polymers because they have polymer parts that absorb the tritium and account for the curie content retained by these valves. It is quite likely that this tritium will be released if these parts directly contact a fire. It is also likely that these parts will degrade with time, and the remaining system is expected to gradually leak over time. There are no plans to mitigate these leaks.

\section{ADDITIONAL TRITIUM NOT INCLUDED IN CHARACTERIZATION}

There is a section of pipe, about 10 feet long, that contains a powder containing $\mathrm{FeO}, \mathrm{FeCl}_{3}$, iron oxide/hydroxide, $\mathrm{Hg}_{2} \mathrm{Cl}_{2}$, and $\mathrm{Hg}_{2} \mathrm{Cl}$ [3]. The tritium content of this so-called "stripper dust" is unknown. Radiography indicates that the pipe containing this powder has remained sound over at least ten years. Because of the hazards associated with sampling this stripper dust, no estimate for the tritium content is available and so none is included in the characterization described in this report.

In addition, there are some locations that contain an undetermined amount of oil. It is anticipated that this oil contains significant quantities of tritium. The amount of oil and its activity are unknown and therefore are not included in this characterization.

This characterization does not include the so-called "Line III" facility, which was characterized previously.

\section{REFERENCES}

1. J.R. Wermer, "Analysis of Residual Tritium in an LP-50 Product Container", Report WSRC-TR-960107 rev. 1, Westinghouse Savannah River Company, Savannah River Site, Aiken SC (4 June 1996).

2. T. Mcgee, email communication, 18 April 2002, Westinghouse Savannah River Company.

3. O.J. Ekechukwu. "232-H Stripper Pipe Pluggage". Report DPD-TED-96-0698, Westinghouse Savannah River Company, Savannah River Site, Aiken SC (1996).

\section{ACKNOWLEDGEMENTS}

The support of J. R. Horton, T. S. Mcgee, G. J. Alexander, A. M. Berglund, D. R. Casares, R. L. Rabun in completing this report is gratefully acknowledged. 
WSRC-TR-2002-00431

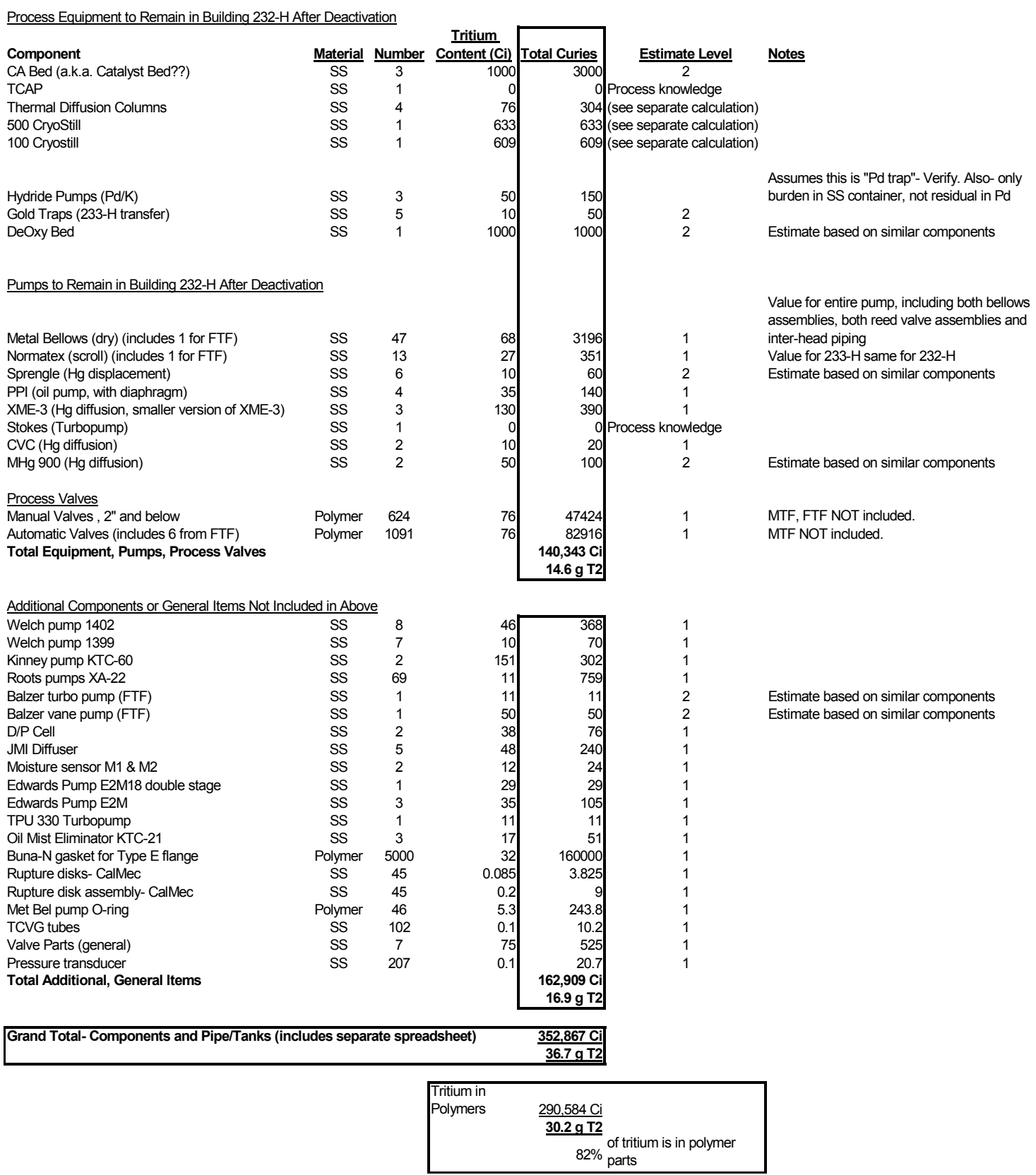

Table I. Listing of Components and Tritium Characterization for Building 232-H. Total tritium content is found by multiplying the number of each component by its estimated tritium content. The Estimate Level for each component describes the how the estimate was made: Level 0: Testing or Verified Calculation, Level 1: Calculation (E7), Level 2: Engineering Judgement. Material: SS is stainless steel (3XX series austenitic). Does NOT include Line III (Extraction furnaces etc.). 


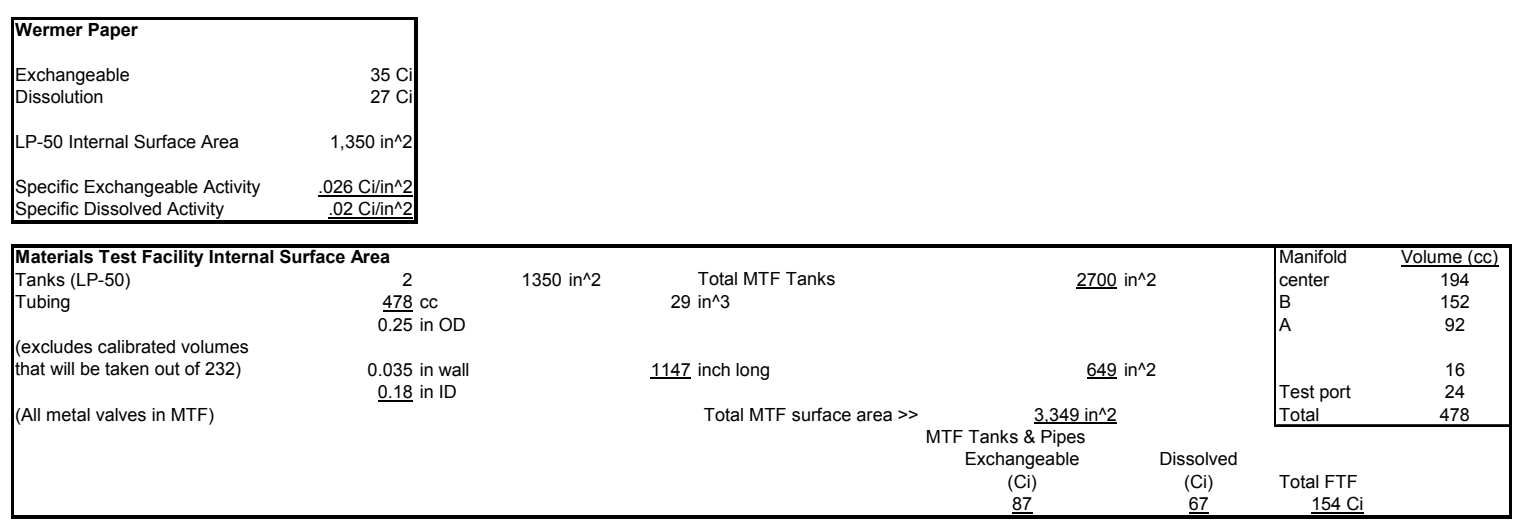

\begin{tabular}{|c|c|c|c|c|c|c|c|c|c|}
\hline \multirow{2}{*}{\multicolumn{3}{|c|}{$\begin{array}{l}\text { Function Test Facility Internal Surface Area } \\
\text { Piping }\end{array}$}} & & & \multirow{2}{*}{\multicolumn{5}{|c|}{ Info coming from Brett Bell per phone conv 1 Aug }} \\
\hline & & & $\frac{\text { Length (feet) }}{36}$ & $\frac{\text { ID (inch) }}{1.049}$ & & & & & \\
\hline & $1 / 2$ & inch pipe & 30 & 0.622 & Assume Schd $40 \mathrm{~S}$ & $\overline{703}$ & & & \\
\hline & $1 / 2$ & inch tube & 15 & 0.430 & Assume 0.035 wall & $\underline{243}$ & & & \\
\hline & $3 / 8$ & inch tube & 55 & $\underline{0.305}$ & Assume 0.035 wall & $\underline{632}$ & & & \\
\hline & & & & & $\begin{array}{l}\text { Total pipe \& tube internal } \\
\text { area: }\end{array}$ & & & & \\
\hline \multirow[t]{6}{*}{ Tanks } & & Volume (liter) & Diameter (inch) & Length (inch) & Area $\left(\mathrm{in}^{\wedge} 2\right)$ & & & & \\
\hline & 2 & 100 & 18 & 22 & 1753 & & & & \\
\hline & 1 & 100 & 12 & 28 & $\overline{1282}$ & & & & \\
\hline & 1 & 230 & 24 & 22 & $\underline{2564}$ & & & & \\
\hline & 1 & 15 & 8 & 22 & $\underline{653}$ & & & & \\
\hline & 1 & 30 & 12 & 18 & $\underline{\underline{905}}$ & & $\begin{array}{l}\text { FTF Tanks \& Pipes } \\
\text { Exchangeable }\end{array}$ & Dissolved & \\
\hline \multirow[t]{2}{*}{ Bell jar } & & 800 & 36 & 48 & 7464 & & (Ci) & (Ci) & Total \\
\hline & & & Total FTF & surface area $\gg$ & $17,624 \mathrm{in}^{\wedge} 2$ & & 457 & $\underline{352}$ & $809 \mathrm{Ci}$ \\
\hline
\end{tabular}

\begin{tabular}{|c|c|c|c|c|c|}
\hline \multicolumn{6}{|c|}{ 232-H Lines I \& II Surface Area and Total Surface Area of Pipe \& Tanks in 232-H } \\
\hline - & $\frac{\text { Surface Area }}{\left(\operatorname{in}^{\wedge} 2\right)}$ & $\frac{\text { Exchangeable }}{(\mathrm{Ci})}$ & $\frac{\text { Dissolved }}{(\text { Ci) }}$ & & \\
\hline Line I Vessels & 305554 & 7922 & 6111 & McGee/Horton & \\
\hline Line II Vessels & 222877 & 5778 & 4458 & McGee/Horton & \\
\hline Line I Piping & 215827 & $\overline{5596}$ & $\overline{4317}$ & McGee/Horton & \\
\hline Line II Piping & 315106 & 8169 & 6302 & McGee/Horton & \\
\hline Materials Test Facility & 3349 & 87 & 67 & See sheet above & \\
\hline Function Test Facility & $\frac{17624}{1762}$ & $\underline{457}$ & $\underline{352}$ & See sheet above & Pipe/Tank Total \\
\hline Total & & 28009 & 21607 & & $49,615 \mathrm{Ci}$ \\
\hline & & 2.91 & 2.25 & & $5.2 \mathrm{~g} \mathrm{~T} 2$ \\
\hline
\end{tabular}

Table II. LP-50 tritium data, MTF, FTF, and Total Line I and Line II 232-H Internal Surface Area and Tritium Estimate from LP-50 data. Internal surface area estimated for each facility knowing system volumes and typical dimensions for pipes and tanks. 
WSRC-TR-2002-00431

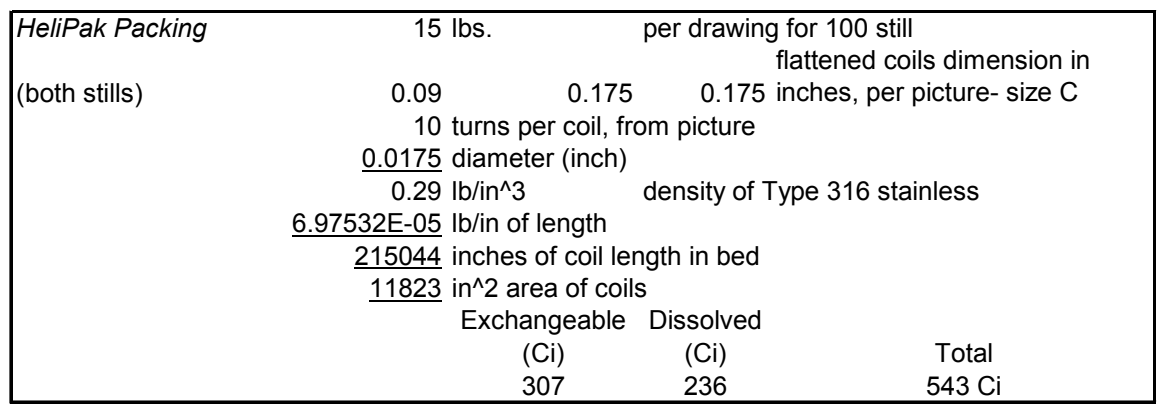

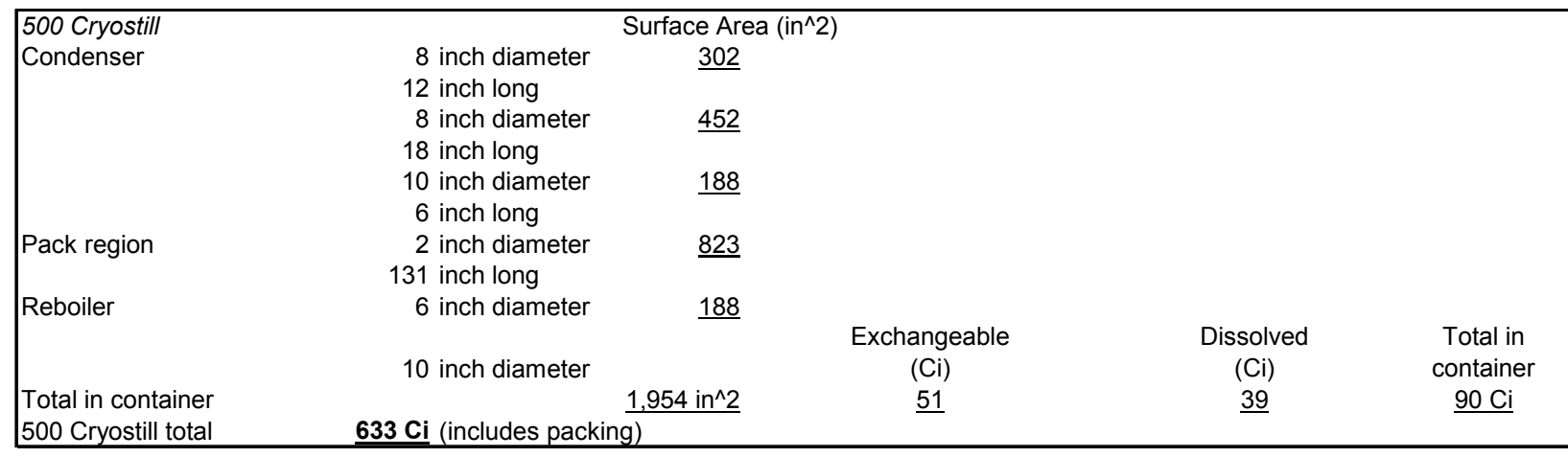

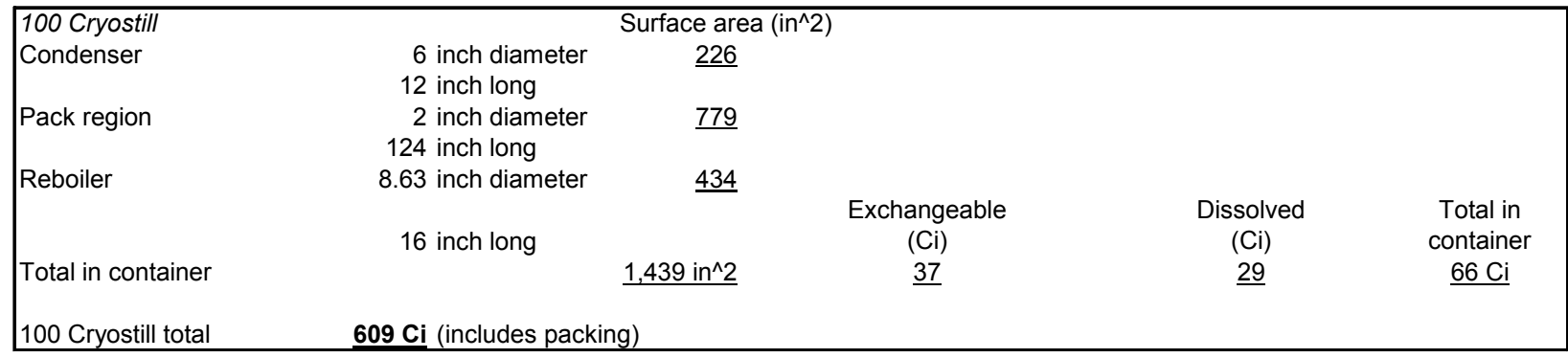

Table III. Estimate of Tritium in Cryogenic Distillation Columns (500- and 100- Cryostills).

\begin{tabular}{|lcc|}
\hline Thermal Diffusion Column \\
Diameter & 1.22 inch \\
Length & 432 inch \\
Surface area & $1,657 \mathrm{in}^{\wedge} 2$ & \\
& & Total in 1 \\
& & Diffusion \\
Exchangeable & Dissolved & Dis \\
$(\mathrm{Ci})$ & $(\mathrm{Ci})$ & Column \\
$\underline{43}$ & $\underline{33}$ & $\underline{76 \mathrm{Ci}}$ \\
\hline
\end{tabular}

Table IV. Estimate of Tritium in one Thermal Diffusion Column. Interior surface area of column calculated. 